\title{
EVALUATION OF TEACHING MATERIALS PREPARED FOR GUIDANCE OF CAREGIVERS AND DAY CARE TEACHERS ON CHILD DEVELOPMENT
}

\author{
Fernanda Alves de Britto Guimarães ${ }^{1}$, Clara Di Assis², Martina Estevam Brom Vieira ${ }^{3}$, \\ Cibelle Kayenne Martins Roberto Formiga ${ }^{4}$
}

DOI: http://dx.doi.org/10.7322/jhgd.96764

\begin{abstract}
:
Objective: to evaluate the clarity and objectivity of a guide with detailed explanations and illustrations about the neurodevelopment of children 0-6 years through the analysis of day care teachers, physical therapists and caregivers. Methods: 23 subjects participated in the study, of which seven were caregivers, seven were teachers and nine were physical therapists. The "Guide of guidelines for the development of children 0-6 years" was prepared by the researchers and subsequently averaged by participants through a questionnaire. Results: The vast majority of survey participants classified the guide as good or excellent $(96 \%)$. All agreed on the language used in the guide as good or excellent and stated that the application of this material favors the stimulation of children's development. Conclusion: The guide proved to be a practical and cost-effective measure that can aid in stimulating child development.
\end{abstract}

Key words: evaluation, educational material, child day care centers, child development, orientation.

\section{INTRODUCTION}

Development is defined as the ability of human beings to perform increasingly complex functions as the result of a constant interaction between an individual's characteristics (intrinsic factors) and the environment in which he/she is inserted (extrinsic factors). Psychomotor development is a successive process that follows the pattern established by the genetic potential of each child and includes a set of responses (reflex, voluntary, spontaneous or learned ones) that are expressed through motor skills, adaptation, language and personal social interaction. ${ }^{1}$

The first years of life are particularly important for child development, as there is rapid brain growth and significant cognitive and sensorimotor advances. ${ }^{2}$ Plasticity occurs in the human brain throughout this period of time, which contributes to the development of children's potentials. ${ }^{3}$

In childhood, and particularly in the early years of schooling, there is significant acquisition of motor skills, which enables the child to have good command of body in different kinds of activity. 4,5 Motor skills acquisition is considered one of the best overall child well-being indicators and it is an easily observed sign of development. As problems of motor coordination and control can extend into adulthood, children with atypical motor development or who are at risk of delays deserve special attention, which will require specific actions. ${ }^{1,3,6}$

Several biological and environmental conditions may increase the likelihood of deficits in child development. The major biological risk factors are prematurity, low birth weight, cardiovascular, respiratory and neurological disorders, and malnutrition. ${ }^{27}$ Environmental risk factors include the physical space where the child lives, parental education, type of family dynamic, the family's purchasing power and family relationships..$^{6,8,9}$

Corrective and preventive actions regarding development deviations depend on the knowledge about the normal and regular sequence of acquisitions of the neuropsychomotor development, which will be used as a basis to provide the most appropriate advice for each situation. Thus, it is important to understand the child's environment and, from then on, match it with the stimulation provided and help improve the child's pace of development.

Early stimulation is an intervention applied early in life to ensure the satisfactory development of the child in evolutionary process. It consists of providing the necessary stimulation with appropriate human contact and exploring objects and spaces in

1 Physical therapist specialized in neuropediatrics intervention, Federal University of São Carlos (UFSCAR), São Carlos, SP, Brazil.

2 Physical therapy student at the State University of Goiás (UEG), Goiânia, GO, Brazil.

3 Physical therapist, Master of Science, Assistant Professor at the Department of Physical Therapy of the State University of Goiás (UEG), Goiânia, GO, Brazil.

4 Physical therapist, PhD in Medical Sciences, associate professor at the Department of Physical Therapy of the State University of Goiás (UEG), Goiânia, GO, Brasil.

Corresponding author: martinabrom@gmail.com

Suggested citation: Guimarãs FAB, et al. Evaluation of teaching materials prepared for guidance of caregivers and day care teachers on child development. Journal of Human Growth and Development. 25(1): 27-40

Manuscript submitted Set 08 2014, accepted for publication Nov 222014. 
the right time and in the correct amount in order to enrich the overall development of the child. ${ }^{10}$ Several studies have shown that there was improved motor skill acquisition in children who received early stimulation. ${ }^{6}$ It is of vital importance to trace the child's progress in the first two years of life, pay attention to motor skill advances, determine if there is any neuropsychomotor deficit, and also study ways to cooperate for a successful development process, once it is the time the body grows larger and matures more rapidly and is consequently more subject to harm. ${ }^{2,11}$

Studies carried out by the Special Education Department show that $50 \%$ of children with any special needs could have achieved a satisfactory development, or even reached the levels of development of other children their age without disabilities, if preventive measures, such as early stimulation, had been adopted. ${ }^{12}$

As important as the structural organization of the physical environment is the presence of a mediator to facilitate the developmental process, and the mediator is every individual who is able to promote someone's development when establishing a relationship. ${ }^{13}$

Parental care is the basis of a child's mental health and this is established during the child's first years of life. Such care plays a key role throughout the child's future path of development. ${ }^{1,14}$ Thus, key relationships, which are necessary for the child's development, care and stimulation, are offered by the family in the home microsystem during childhood. ${ }^{13,15}$

However, as a result of the socioeconomic changes that society is undergoing, such as the inclusion of women in the labor market, child care centers have become increasingly necessary in Brazil. Child care centers are institutions which take on the responsibility of caring for preschool children ( 0 to 6 years). ${ }^{5,11}$ Literature shows great concern about the impact of the enrollment of increasingly younger children in child care centers and their staying there for long periods of time, especially with regard to their cognitive, language, socialemotional and behavioral development. As kids stay in care centers from eight to ten hours a day, it is important to promote child development in these institutions. ${ }^{4}$

Thus, child care centers are meant to develop educational practices that might contribute to children's development as if they were with their parents. ${ }^{15}$ However, some studies found that these institutions primarily aim to keep children healthy and safe and end up neglecting their educational role and the search for children's global development, which may result in developmental delay. ${ }^{17}$

By knowing children's growth and development conditions in day care centers, health promotion and disease prevention programs can be implemented, which can be helpful for children's healthy and harmonious development. ${ }^{11}$ Often, developmental delays will only be noticed after preschool age. ${ }^{18}$ Thus, professionals who work with children 0-6 years should consider studying measures that might contribute to preventing neuropsychomotor delay.
Therefore, we can point out the relevance of monitoring children's development in institutions of early childhood education by specialized professionals, which enables the analysis of children's development in their early years, the identification of the children who are at higher risk for developmental delays and consequently the establishment of intervention strategies and development promotion. . $^{8,19}$

Given the importance of stimulating children's neuropsychomotor development to promote harm prevention, the objective was to analyse educational material designed to guide child care center teachers who work for the Municipal Centers of Children's Education (CMEIs) as well as care givers about child development from birth to six years old.

\section{METHODS}

This study is connected to an Extension Program entitled "Guidance for caregivers of public child care centers in Goiânia on child development" developed by professors and students of the Physical Therapy Program of the State University of Goiás (UEG), supported by the public notice PROEXT 2013 of the Ministry of Education (MEC). Therefore, one of the suggested ways to stimulate the development of children who attend day care centers (CMEIs) in Goiânia (GO) was to develop and assess the objectivity and applicability of an educational material which is supposed to guide care givers and teachers of those institutions on child development.

CMEIs are public institutions subordinated to the Municipal Education Department that serve children from six months to five years and 11 months of age and have the overall objective of promoting the development of children in their physical, psychological, intellectual and social aspects in order to integrate care giving and education in accordance to the Law of Guidelines and Bases of Education (LDBEN, law no. 9.394/96).

Twenty-three individuals took part in the study: seven teachers who work at a CMEI in Goiânia (GO), seven parents and/or guardians of children who attend the day care centers and nine physical therapists.

Inclusion criteria were as follows:

- Teacher at a CMEI in Goiânia (GO)

- Parent and/or guardian of children 0-6 years who attend a CMEI and who have finished primary school.

- Physical therapists, specialists in Child Neurology or Pediatrics, or physical therapists specialized in Neurofunctional Physiotherapy with experience of more than three years in Neuropediatrics who live and/or work in Goiânia (GO).

The study excluded individuals who did not agree to participate in the study and that did not sign the consent form; those who did not live and/ or work in Goiânia (GO); and those who did not fully answer the questionnaire, which was taken as necessary to achieve the objective of this study.

The survey was conducted in accordance with the Regulatory Norms of Research Involving Human 
Subjects (Resolution 196/1996 of the National Health Council) and was approved by the Research Ethics Committee of UFSCar (through SISNEP Brazilian National System of Ethics Committee) and by the Municipal Department of Educations of Goiânia-GO.

At the time of data collection, the study objectives were presented to participants both orally and in writing through a Consent Term. Given their agreement, the term was signed by the participant and the researcher, as per the provisions contained in the Resolution 196/96 of the National Health Council (1998).

The data collection site was set up according to each research group. The teachers were approached in their own day care centers after a scheduled visit to the place, in the staff room. Parents and/or guardians were also approached in the day care centers their children go to as they were pre-selected by the coordinator of the school at the time students arrive and leave. Physical therapists were approached in their workplaces after a prior appointment or at the Interdisciplinary Research Center (NIPE), which is located in the Superior School of Physical Education and Physiotherapy of the State of Goiás - ESEFFEGO, as well as through e-mail. The data were stored, organized and analyzed at the NIPE.

The instruments used in this study were:

- Free and clarified Consent Term;

- "Personal Data Sheet" for each participant with the following requirements: age, gender, specialization (physical therapists), educational level (parents and/or guardians), along with questions of the "Assessment questionnaire of the educational material." The participants were asked about: the overall evaluation of the guide; how much it can favor children's development; if the individual learned something new; whether it was possible to apply the material or not; if they had any questions about its content and application; if they found it difficult to apply; language assessment; their opinion about the guide's illustrations; if it included all areas of development; and their satisfaction with CMEI services (to parents and teachers).

- Guide written by the authors, educational material with language accessible to the population in general, illustrated activities to help parents and caregivers stimulate children aged zero to six years so they can have a normal development. Literature on child development was presented as theoretical framework. 20,21,22

The materials and equipment used were: pens, A4 paper, printer, computer, SPSS (version 18.0) for data analysis.

The guide was written after a detailed review of literature, and data were collected as described below: visits to child care centers were scheduled with anticipation so that the material could be delivered to teachers and parents and personal data could be collected; the objectives of the study were presented to participants both orally and in writing on the scheduled day. As agreed, the free and clarified consent term was signed both by participants and researchers. With the material at hand, the questionnaire was applied in order to analyze possible difficulties people could have when dealing with it. Parents were approached when they were arriving or leaving the day care center so that their daily activities were not affected.

Physical therapists could also schedule their appointments with anticipation and choose the place to hand out the material and for the interview: their own workplace, NIPE or via e-mail. The material was handed out and personal data were collected and, with the material at hand, the assessment questionnaire was applied.

After the data collection phase, such data were arranged in databases. For the analysis of the responses to the questionnaire, respondents were divided into three groups: parents, teachers and physical therapists. It was made a descriptive analysis of the data collected by using SPSS (version 18.0).

\section{RESULTS}

The sample subjects were divided into three groups: seven teachers, seven parents and/or guardians of children who attend day care centers and nine physical therapists $(n=23)$.

Table 1 shows the personal data of the respondents of each group (parents, teachers and physical therapists) and provides a detailed description of the assessment.

It is observed in Table 1 that most of the people of the group of parents (caregivers) were female $(71 \%)$, and there was no prevailing occupation among them. A parent refused to provide his personal data, such as: occupation, age, and educational level. With regard to parental education, $28 \%$ had secondary degree and $28 \%$ had higher education.

In the group of teachers, the vast majority was also female ( $86 \%)$. It is worth pointing out that more than a half of the teachers who were interviewed had an postgraduate degree in the fields of Neuropedagogy, Literacy, Psychopedagogy or School Management. Regarding the characteristics of the group of physical therapists, the females prevailed $(89 \%)$ and most of them had a graduate degree $(89 \%)$ in the fields of Neuropediatrics and/ or Neurofunctional Physical Therapy. These results show that the groups of evaluators were well qualified in their respective fields of study to assess the quality and applicability of the proposed guide.

According to the items to assess the guide shown in Table 1, all participants provided positive comments when asked if the guide would contribute to development stimulation. All the parents and teachers concluded that they had learned something new when reading the material and almost half of the physical therapists also reported that they had learned something new when they read the guide.

When asked about the difficulty in applying the material proposed, a parent and a teacher said they would have difficulties. The teacher who said he would have difficulties in applying it mentioned "time" as an obstacle. The rest of the participants said they had no doubts about the content, which could show that the guide is efficient and instructive 
Table 1: Personal data of evaluators and assessment of guide of guidelines

\begin{tabular}{|c|c|c|c|c|}
\hline Evaluators' Personal Data & $\begin{array}{l}\text { Parents } \\
(\mathrm{n}=7)\end{array}$ & $\begin{array}{l}\text { Teachers } \\
(n=7)\end{array}$ & $\begin{array}{l}\text { Physiotherapists } \\
\qquad(n=9)\end{array}$ & $\begin{array}{l}\text { Total Sample } \\
\qquad(n=23)\end{array}$ \\
\hline \multicolumn{5}{|l|}{ Personal Data } \\
\hline Age - mean $(S D)$ & $33( \pm 7)$ & $32( \pm 5)$ & $33( \pm 8)$ & $33( \pm 7)$ \\
\hline Femaleparticipants- f (\%) & $5(71)$ & $6(86)$ & $8(89)$ & $19(83)$ \\
\hline \multicolumn{5}{|l|}{ Escolaridade $^{1}-\mathrm{f}(\%)$} \\
\hline Primary Degree & $1(14)$ & 0 & 0 & $1(4)$ \\
\hline High School & $2(28)$ & $2(28)$ & 0 & $4(17)$ \\
\hline Undergraduate Degree & $2(28)$ & $1(14)$ & $1(11)$ & $4(17)$ \\
\hline Graduate Degree & $1(14)$ & $4(58)$ & $8(89)$ & $14(62)$ \\
\hline \multicolumn{5}{|l|}{ GuideAssessment } \\
\hline \multicolumn{5}{|l|}{ General Evaluation - f (\%) } \\
\hline Fair & 0 & 0 & $1(11)$ & $1(4)$ \\
\hline Good & $1(14)$ & $2(28)$ & $5(55)$ & $8(35)$ \\
\hline Excellent & $6(86)$ & $5(72)$ & $3(34)$ & $14(61)$ \\
\hline \multicolumn{5}{|l|}{ Assessment of language used - $\mathrm{f}(\%)$} \\
\hline Good & $3(43)$ & $3(43)$ & $7(77)$ & $13(56)$ \\
\hline Excellent & $4(57)$ & $4(57)$ & $2(23)$ & $10(44)$ \\
\hline \multicolumn{5}{|l|}{ Shall promote children's } \\
\hline development - $f(\%)$ & $7(100)$ & $7(100)$ & $9(100)$ & $23(100)$ \\
\hline Learnedsomething new - $f(\%)$ & $7(100)$ & $7(100)$ & $4(44)$ & $18(78)$ \\
\hline What is taught can be applied - $\mathrm{f}(\%)$ & $7(100)$ & $7(100)$ & $9(100)$ & $23(100)$ \\
\hline Had no doubts about content - $f(\%)$ & $6(86)$ & $6(86)$ & $7(77)$ & $19(83)$ \\
\hline $\begin{array}{l}\text { Thought there would beno difficulties in } \\
\text { applying it }{ }^{2}-f(\%)\end{array}$ & $6(86)$ & $6(86)$ & $8(89)$ & $20(87)$ \\
\hline \multicolumn{5}{|l|}{ Illustrations are adequate to } \\
\hline \multicolumn{5}{|l|}{ Comprises all areas } \\
\hline of development ${ }^{2}-f(\%)$ & $7(100)$ & $6(86)$ & $7(77)$ & $20(87)$ \\
\hline $\begin{array}{l}\text { Satisfied with the services provided } \\
\text { by the CMEI - } f(\%)\end{array}$ & $7(100)$ & $6(86)$ & NA & NA \\
\hline
\end{tabular}

Note: 1 one parent did not answer this question; 2 one physical therapist did not answer this question. SD - Standard Deviation; $\mathrm{f}$ - frequency; \% - percentage; $\mathrm{n}$ - number of participants; NA - not applicable.

in the propagation of the guidelines on children's neuropsychomotor development.

The sample as a whole had a positive assessment about the illustrations of some of the exercises for children's stimulation. Three participants (one teacher and two physical therapists) said that the material did not cover all areas of development; however, they were not able to clarify what these other areas would be.

With regards to parents and teachers' satisfaction with the service provided by the CMEIs, only one teacher of the 14 participants was not satisfied, but did not explain why.

With regard to the general evaluation of the guide, considering all the evaluators, most evaluators described the material as "excellent". It is worth pointing out that no participant considered the guide as "bad" and only one physical therapist said that it was "fair". In addition, all the evaluators graded the language used as "good" or "excellent".

\section{DISCUSSION}

The objectives of this study were to produce an educational material with detailed explanations and illustrations in order to assist care givers and teachers who work for child care centers with regards to neurological development of children 06 years; and assess the clarity and objectivity of such material, after analysis of day care teachers, physical therapists and care givers of children 0-6 years.

Environmental conditions are one of the risk factors that may cause developmental delay in children. A good environment for child development should provide supportive relationships, promote their physical security and safety, protect them against diseases, supply their basic needs, etc. In general, a child spends most of the time with the family. However, children whose parents work full time usually stay in day care centers for a considerable long period of time, being educated and stimulated by teachers. ${ }^{22}$ In order to ease the process, both for parents and teachers, this project aimed to present a material that could provide additional developmental stimulation to children's daily activities in an easy and simple way.

Regarding the profile of the evaluators who were part of the sample, it was observed that the average age of the groups was 32 and 33 years. Females prevailed in all groups. Regarding the educational level, two participants had only primary degree. The parents' high educational level made the guide easier to be understood, which can be observed when it was asked whether the language was easy to understand or not. The group "Parents" classified the guide as good (14\%) and excellent $(86 \%)$. The higher the mother's education level, the better the physical and temporal environments will be organized, the greater the opportunities to vary daily stimulation with availability of appropriate materials and games for children and greater 
emotional and verbal involvement of mothers with the child. ${ }^{2}$ However, the study by Santos et al. ${ }^{23}$ found no association between maternal education and the development of preschool children who attend public or private schools.

With regards to schooling, only one physical therapist had not yet achieved a graduate degree. All the other physical therapists had a postgraduate degree in Neuropediatrics or Neurofunctional Physical Therapy. When assessing the guide in general, physical therapists were more demanding than the other two sample groups, since most of them classified it as "good" (55\%). The other groups classified it as "excellent" in general. The group of physical therapists mostly answered that they had not learned anything new from the material (56\%), whereas all participants in the other groups stated they had learned something new. Thus, we can conclude that the guide has increased parents' and teachers' knowledge on child development (0-6 years). This knowledge will be able to be applied to the children's lives and prevent neuropsychomotor developmental delay.

In two other studies, ${ }^{24,25}$ it was meant to make and assess a material that could help stimulate child development. An educational booklet named "Toda hora é hora de cuidar" ("Anytime is time to care") was created and its authors questioned parents and health professionals (Community Health Workers) about its validity and the effectiveness. Some reported finding it difficult toapply. One of the reasons given was "lack of time", the same reason given by one of the CMEI teachers who belonged to the study sample. Another reason was the fact that many children usually spend most of the day at school, which shows that the material is supposed to be used by the teachers themselves, which is something proposed by this study.

Nevertheless, the guide was classified as adequate and important in promoting child development and also as having appropriate language and content, mainly by those community workers and family members who had been trained in its application and had a higher educational level. Teixeira et al. ${ }^{26}$ came to similar conclusions when they proposed to validate an educational technology for riverine families. The "Guide of guidelines for the development of children 0-6 years" was also favorably evaluated and considered as efficient by the majority of the sample group members.

In addition, other studies ${ }^{27,28}$ have pointed out that the use of educational and instructional materials makes practice easier, promotes standardization of guidelines in order to avoid contradictory information and also enables memorization of the material content by the people who apply it.

All participants of this study said that the educational material favored the development of children at CMEIs, and all of them said it should be applied in these institutions. Early identification of signs of delay from the first months of life can reduce the time it takes to start children's developmental stimulation, which may reduce alterations in the development of children. ${ }^{29}$ While acknowledging that early interventions in the public health and education system may be more difficult to implement, there are numerous alternatives to promote low-cost programs. ${ }^{30}$ Simple measures such as the stimulation of adult-guided play ${ }^{31}$ or activity-focused interventions and guidance through recreational activities can have positive effects on children's development and behavior. The same occurs regarding this Stimulation Guide, which shows its potential, as per the evaluators' opinion, in assisting both in the identification of children's developmental delays and in providing guidelines for care givers so that they can perform neuropsychomotor stimulation.

About the service provided in CMEIs, the vast majority of parents and teachers stated they were satisfied with the institution. The importance of checking the satisfaction of participants is related to the amount of time children spend in CMEIs and the quality of the stimulation given during the period of time children are under the teachers' care, once it is necessary that the care provided meet their needs and favorably influence their neuropsychomotor development. ${ }^{4}$ In contrast, a study by Campos et al., ${ }^{33}$ who assessed the quality of 147 educational institutions (child care centers and preschools) in six Brazilian State capitals, could verify that most institutions had an impaired level of quality as well as deficits in infrastructure, pedagogical guidance (activities) and personal care routines.

There are several factors that can negatively influence CMEIs with regards to the creation of a favorable environment for the development of children and an individualized comprehensive care, such as: physical space limitations (limited space for sports and physical activities), economic constraints (lack of suitable teaching and educational materials), reduced amount of teachers and inadequately qualified teachers. ${ }^{34}$ This inadequate environment can reflect negatively on the development of children who attend public day care centers compared with the children who attend private schools. ${ }^{23}$

By contrast, a study analyzed the growth of preschool children in day care centers in GoiâniaGO, and it was observed that most children had growth and development within the normal range. ${ }^{11}$ The role of CMEIs proved to be vital for the result, once they have a social and political task of providing the child a good quality education, through which the child can expand physical, cultural and social knowledge in such a way that it cannot be separated from the tasks of caring and educating. ${ }^{35}$ It can be said, then, that the services that CMEIs in Goiânia claim they can provide in terms of education and child care have been successfully performed, if we take into account the opinion of parents and teachers.

In the study carried out in child care centers in Goiânia-GO, the findings suggest that the most impaired area of development during the assessments was language. ${ }^{11}$ One possible explanation given by the authors was that social factors related to stimulation were poor and therefore insufficient for the development of linguistic patterns. Some other explanations given by them were related to the fact that children stay 
at the CMEIs full time and used to have little contact with parents. Another reason might be related to the fact that agre at amount of children were under the responsibility of a very small amount of care givers, which may hinder the child's language development as basic routine-care activities takes most of the time. ${ }^{11}$ The guide can help parents and teachers prevent deficits in several different areas related to child's development, such as language, with simple and easy-to-apply activities, as stated by the evaluators in this study.

The positive impact of early intervention programs on child development and on their subsequent school performance justifies the need for early identification of children at risk for delays and the consequent intervention before the problems set in. ${ }^{36}$ Thus, the aim of this study, which is to propose the creation of an educational material with guidelines, as well as its assessment under different points of view (family, school and therapist) that may influence the neuropsychomotor development of children, focuses on shared care, which aims to increase interaction between the

\section{REFERENCES}

1. Degenszajn RD. Teorias sobre o Desenvolvimento Neuropsicomotor da Criança: uma revisão crítica. In: Marcondes E, Vaz FAC, Ramos JLA, Okay Y. Pediatria Básica: Tomo I - Pediatria Geral e Neonatal. 9. ed. São Paulo: Sarvier; 2003; p. 36-45.

2. Eickmann SH, Maciel AMS, Lira PIC, Lima MC. Fatores associados ao desenvolvimento mental e motor de crianças de quatro creches públicas de Recife, Brasil. Rev Paul Pediatr. 2009; 27(3): 282-288. Doi: http://dx.doi.org/ 10.1590/S0103-05822009000300008.

3. Baltieri L, Santos DCC, Gibim NC, Souza CT, Batistela ACT, Tolocka RE. Desempenho motor de lactentes frequentadores de berçários em creches públicas. Rev Paul Pediatr. 2010; 28(3): 283-289. Doi: http://dx.doi.org/10.1590/ S0103-05822010000300005 .

4. Biscegli TS, Polis LB, Santos LM, Vicentin M. Avaliação do estado nutricional e do desenvolvimento neuropsicomotor em crianças freqüentadoras de creche. Rev Paul Pediatr. 2007; 25(4): 337-342. Doi: http://dx.doi.org/ 10.1590/S0103-05822007000400007.

5. Rosa Neto F, Santos APM, Xavier RFC, Amaro KNA. Importância da avaliação motora em escolares: análise da confiabilidade da Escala de Desenvolvimento Motor. Rev Bras Cineantropom Desempenho Hum. 2010; 12(6):422-427. Doi: http://dx.doi.org/ 10.5007/1980-0037.2010v12n6p422.

6. Willrich A, Azevedo CCF, Fernandes JO. Desenvolvimento motor na infância: influência dos fatores de risco e programas de intervenção. Rev Neurocienc. 2009; 17(1): 51-56.

7. Vieira MEB, Linhares MBM. Desenvolvimento e qualidade de vida em crianças nascidas pré- family and school and take into account the different points of view for the sake of the child. ${ }^{37}$

\section{CONCLUSION}

This study showed that the education material prepared for the guidance of parents and day care teachers on child development stimulation proved to be clear, objective and efficient in parents', teachers' and physical therapists' opinion. Therefore, the guide was favorably evaluated by the various participants and no changes to the material were considered necessary.

The scope of the study of child development is broad and includes its relation with numerous environmental and biological risk factors. The implementation of health promotion and prevention measures should consider the complexity that involves opportunities and the socioeconomic conditions of the population. Study in low-cost practical measures to improve people's quality of life and to provide knowledge to the population is absolutely necessary, and that is one of the roles of health professionals. termo em idades pré-escolar e escolar. J Pediatr. 2011; 87(4): 281-291. Doi: http://dx.doi.org/ 10.2223/JPED.2096.

8. Souza CT, Santos DCC, Tolocka RE, Baltieri L, Gibim NC, Habechian FAP. Avaliação do desempenho motor global e em habilidades motoras axiais e apendiculares de lactentes frequentadores de creche. Rev Bras Fisioter. 2010; 14(4): 309-315. Doi: http://dx.doi.org/10.1590/ S1413-35552010000400007.

9. Pedraza DF, Menezes TN. Fatores de risco do déficit de estatura em crianças pré-escolares: estudo caso-controle. Ciênc Saúde Coletiva. 2014; 19(5): 1495-1502. Doi: http:// dx.doi.org/10.1590/1413-81232014195. 21702013.

10. Brasil. Ministério da Educação e Cultura/ Secretaria de Educação Especial. Diretrizes educacionais sobre estimulação precoce: o portador de necessidades especiais. Brasília: a Secretaria, MEC/SEESP, 1995.

11. Braga AKP, Rodovalho JC, Formiga CKMR. Evolução do crescimento e desenvolvimento neuropsicomotor de crianças pré-escolares de zero a dois anos do município de Goiânia (GO). Rev Bras Crescimento Desenvolv Hum. 2011; 21(2): 230-239.

12. Pinheiro RC, Martinez CMS, Pamplin RCO. Suporte informativo para educadores de creche: risco e proteção nos primeiros anos de vida. Cad Ter Ocup UFSCar. 2010; 18(2): 129-138.

13. Nobre FSS, Costa CLA, Oliveira DL, Cabral DA, Nobre GC, Cacola P. Análise das oportunidades para o desenvolvimento motor (affordances) em ambientes domésticos no Ceará - Brasil. Rev Bras Crescimento Desenvol Hum. 2009; 19(1): 9-18.

14. Pinhel J, Torres N, Maia J. Crianças institucionalizadas e crianças em meio familiar de vida: 
Representações de vinculação e problemas de comportamento associado. Aná Psicológica. 2009; 27(4): 509-521.

15. Alvarenga $P$, Piccinini $C$. Práticas educativas maternas e problemas de comportamento em pré-escolares. Psicol Reflex Crit. 2001; 14(3): 449-460. Doi: http://dx.doi.org/10.1590/ S0102-79722001000300002.

16. Nascimento MLBP. A creche na educação infantil: entre o ofício e o direito. Estud Sociol. 2010; 15(29): 555-66.

17. Santos DC, Tolocka RE, Carvalho J, Heringer LR, Almeida CM, Miquelote AF. Gross motor performance and its association with neonatal and familial factors and day care exposure among children up to three years old. Rev Bras Fisioter. 2009; 13(2): 173-179. Doi: http:// dx.doi.org/10.1590/S1413-3555200900 5000025.

18. Schmidhauser J, Caflisch J, Rousson V, Bucher $\mathrm{HU}$, Remo $\mathrm{H}$, Largo MD. Impaired motor performance and movement quality in verylow-birthweight children at 6 years of age. Dev Med Child Neurol. 2006; 48(9): 718-22. Doi: http://dx.doi.org/10.1017/S001216220 600154X.

19. Formiga CKMR, PedrazzaniES, Tudella E. Intervenção precoce com bebês de risco. São Paulo: Atheneu; 2010.

20. Liddle TL, Yorke L. Coordenação Motora. São Paulo: M. Books do Brasil; 2007.

21. Tisi L. Estimulação precoce para bebês. Rio de Janeiro: Spring; 2004.

22. Lamy Filho F, Medeiros SM, Lamy ZC, Moreira ME. Ambiente domiciliar e alterações do desenvolvimento em crianças de comunidades da periferia de São Luis - MA. Ciênc Saúde Coletiva. $2011 ; 16(10)$ : 4181-4187. Doi: http:// dx.doi.org/10.1590/S1413-8123201100 1100023.

23. Santos MM, Corsi C, Marques LAP, Rocha NACF. Comparação do desempenho motor e cognitivo de crianças frequentadoras de creches públicas e particulares. Braz J PhysTher. 2013; 17(6): 579-587. Doi: http://dx.doi.org/ 10.1590/S1413-35552012005000126.

24. Grippo MLVS, Fracolli LA. Avaliação de uma cartilha educativa de promoção ao cuidado da criança a partir da percepção da família sobre temas de saúde e cidadania. Rev Esc Enferm USP. 2008 ; 42(3): 430-436. Doi: http:// dx.doi.org/10.1590/S0080-6234200 8000300003

25. Martins J, Veríssimo MDLOR, Oliveira MA. Avaliação dos instrumentos do projeto "nossas crianças: janelas de oportunidades", segundo agentes comunitários de saúde. Texto Contexto Enferm. 2008; 17(1): 106-114. Doi: http:/ /dx.doi.org/10.1590/S0104-07072008 000100012.

26. Teixeira E, Siqueira AA, Silva JP, Lavor LC. Cuidados com a saúde da criança e validação de uma tecnologia educativa para famílias ribeirinhas. Rev Bras Enferm. 2011; 64(6): 10031009. Doi: http://dx.doi.org/10.1590/S003471672011000600003.

27. Fonseca LMM, Scochi CGS, Rocha SMM, Leite AM. Cartilha efucativa para orientação materna sobre os cuidados com o bebê prematuro. Rev Latino-Am Enfermagem. 2004; 12(1): 6575. Doi: http://dx.doi.org/10.1590/S010411692004000100010.

28. Reichert APS, Vasconcelos MGL, Eickmann SH, Lima MC. Avaliação de implementação de uma intervenção educativa em vigilância do desenvolvimento infantil com enfermeiros. Rev Esc Enferm USP. 2012; 46(5): 1049-1056. Doi: http://dx.doi.org/10.1590/S008062342012000500003.

29. Resegue R, Puccini RF, Silva EMK. Fatores de risco associados a alterações no desenvolvimento da criança. Pediatria (São Paulo). 2007; 29(2): 117-128.

30. Halpern R, Giugliani ERJ, Victora CG, Barros FC, Horta BL. Fatores de risco para suspeita de atraso no desenvolvimento neuropsicomotor aos 12 meses de vida. J Pediatr. 2000; 76(6): 421-428.

31. Bonome-Pontoglio CF, Marturano EM. Brincando na creche: atividades com crianças pequenas. Estud Psicol (Campinas). 2010; 27(3): 365-373. Doi: http://dx.doi.org/10.1590/ S0103-166X2010000300008.

32. Soejima CS, Bolsanello MA. Programa de intervenção e atenção precoce com bebês na Educação infantil. Educ Rev. 2012; (43):65-79. Doi: http://dx.doi.org/10.1590/S010440602012000100006.

33. Campos MM, Esposito $Y L$, Bhering E, Gimenes N, Abuchaim B. A qualidade da educação infantil: um estudo em seis capitais brasileiras. Cad Pesqui. 2011; 41(142): 20-54. Doi: http:/ / dx. do i.org/10.1590/S0100 15742011000100003.

34. Campos MM, Fullgraf J, Wiggers V. A qualidade da educação infantil brasileira: alguns resultados de pesquisa. Cad Pesqui. 2006; 36(127): 87-128. Doi: http://dx.doi.org/10.1590/ S0100-15742006000100005.

35. Sabatés AL, Mendes LCO. Perfil do crescimento e desenvolvimento de crianças entre $12 \mathrm{e}$ 36 meses de idade que freqüentam uma creche municipal da cidade de Guarulhos. Ciênc Cuid Saúde. 2007; 6(2): 164-170.

36. Pilz EML, Schermann LB. Determinantes biológicos e ambientais no desenvolvimento neuropsicomotor em uma amostra de crianças de Canoas/RS. Ciênc Saúde Coletiva. 2007; 12(1): 181-190. Doi: http://dx.doi.org/10.1590/ S1413-81232007000100021.

37. Maranhão DG, Sarti CA. Creche e família: uma parceria necessária. Cad Pesqui. 2008; 38(133): 171-1940. 


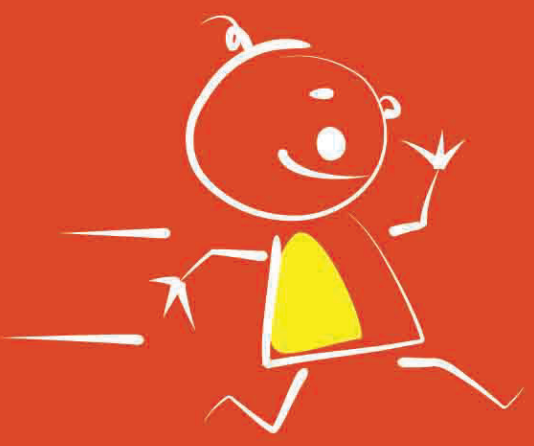

Guide of guidelines on the development of children $(0-6$ years $)$

Fernanda Alves de Britto Guimarães Cibelle Kayenne Martins Roberto Formiga Martina Estevam Brom Vieira

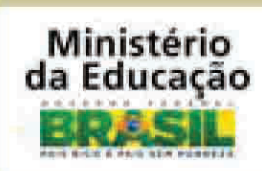

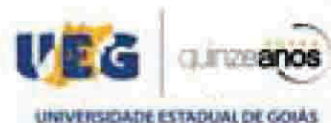




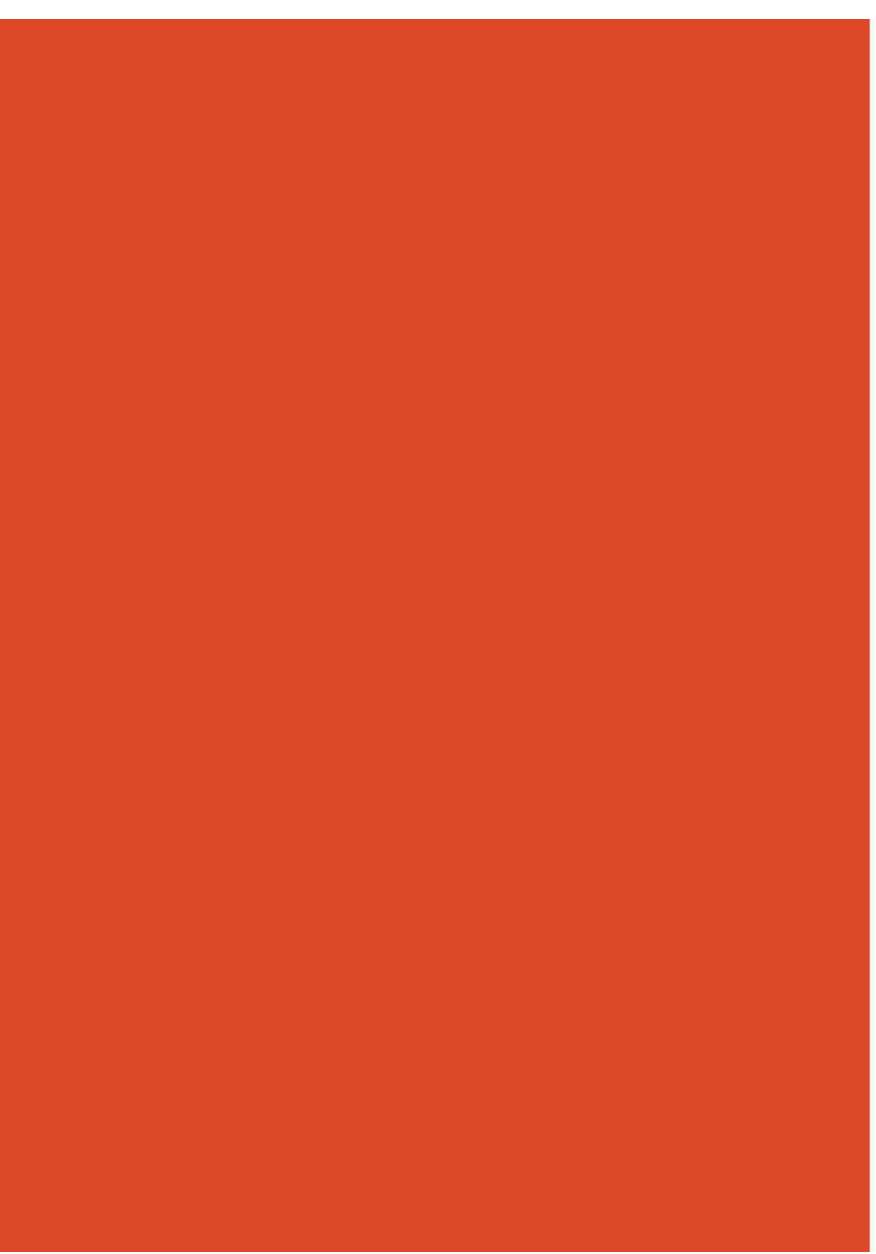

\section{Guide of guidelines on the development of children (0-6 years)}
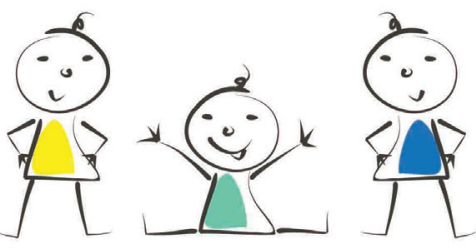

Fernanda Alves de Britto Guimarães Cibelle Kayenne Martins Roberto Formiga Martina Estevam Brom Vieira

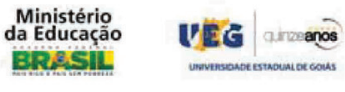

\section{Introduction}

Child development comprises continuous changes in a child's function and each new skill represents another step towards the achievement of independence and social adaptation. The first years of a child's life are critical for development as there is rapid physical growth and intense motor and cognitive advancements. These new skills can be stimulated as a warm and challenging environment is provided for the child. The role of parents, teachers and other caregivers is essential in this process. Therefore, their knowledge about the development process and on the various activities or games that could be performed with the child can lead to positive steps that could be easily undertaken.

In this context, the "Guide of Guidelines on the development of children (0-6 years)" was designed by the specialized physiotherapist Fernanda Alves de Britto Guimarães, under the guidance of the Masters, Professors Martina Estevam Brom Vieira and Cibelle Kayenne Martins Roberto Formiga, as a result of the Extension Program entitled "Guidance to Caregivers of Public Kindergartens on Child Development" at the State University of Goiás (UEG), which also includes the participation of School of Physical Therapy students (ESEFFEGO). The main objective of this project is to favor preschool children's development through the identification of risk factors that may be present in this population, and consequently provide caregivers guidance and training about the concepts that involve child development and how to stimulate it.

Universidade Estadual de Goiás

Prof. Haroldo Reimer

Profa. Valcemia Golnçalves de Sousa Novaes Vice-rector

\section{Vhe quinzeanos}

Cover page and graphic design

Thiago Martins de Oliveira 
This guide is a practical and cost-effective measure of prevention and health promotion once it shows how effective this is in guiding parents, teachers and other caregivers of children 0-6 years. The guide was divided into topics and contains several illustrations and simple language in order to make it easy to be read and understood by all. It provides information about the expected behavior of children according to their age group. It also presents ways to stimulate child development, with instructions and examples of various forms of stimuli that include the four major areas: personal social relationship (child's ability to interact with others and self-help activities), language (production and reaction to sounds, recognition and use of language), fine motor adaptive skills (manipulative activities involving coordination of small muscles and eye-hand coordination) and gross motor skills (ability to use large muscle groups to maintain postural control).

\section{Sumário}

1. Newborn development (0-1 month) $\ldots \ldots \ldots \ldots \ldots \ldots$.

How to stimulate your baby $(0-1$ month $) \ldots \ldots \ldots \ldots .9$

2. Newborn development (1-3 months) ............10 How to stimulate your baby $(1-3$ months $) \ldots \ldots \ldots \ldots 11$

3. Newborn development (4-6 months) ...........12 How to stimulate your baby (4-6 months) . . . . . . . 13

4. Newborn development (7-9 months) $\ldots \ldots \ldots \ldots \ldots 14$ How to stimulate your baby $(7-9$ months $) \ldots \ldots \ldots \ldots 15$

5. Newborn development (10-12 months) $\ldots \ldots \ldots \ldots \ldots 16$ How to stimulate your baby (10-12 months) . . . . . . . 17

6. Newborn development $(1-3$ years $) \ldots \ldots \ldots \ldots \ldots \ldots 18$

How to stimulate your baby (1-3 years) . . . . . . . . . . . . 19

7. Newborn development (3-6 years) . . . . . . . . . 20 How to stimulate your baby $(3-6$ years $) \ldots \ldots \ldots \ldots \ldots 21$

References . . . . . . . . . . . . . . . . . . . . 22

\section{The child can/will:}

- Focus on faces and objects 20-30 centimeters away and track objects 90 degrees.

- Perform some simple facial expressions (as poking out the tongue).

- Turn to the sound of your voice and turn head to the other side when perceiving danger (such as a sudden movement within his or her visual field).

- Get scared when he/she hears a very loud noise.

- Calm down when putting objects in his/her mouth.

- Feel soothed and snuggle when in your lap.

- Turn his/her head towards the pacifier or the feeding bottle when it touches his/her lip.

- Lift head momentarily to turn it to sides.

- Grasp his/her finger or toy.

- Easily move arms and legs randomly.

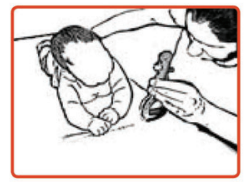

Encourage better control of head and trunk by placing the baby face down. Grab the baby's attention with toys so that he/she lifts his/her head.

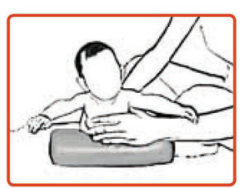

Also for better control of head and trunk, roll up a towel or blanket and put the baby on. Support the baby's chest and back and allow the baby to try this position for a while once it provides muscle contraction of the back.

With the baby lying on his back, you can stimulate better body alignment and also motor skills such as hand-to-hand and handobject movements. Always remember to put the objects at a distance $20-30 \mathrm{~cm}$ away from the baby's eyes. 


\section{The child can/will:}

- Smile.

- Recognize faces.

- Follow moving object to midline.

- Start responding when you are out of sight and begin to get a sense of object permanence.

- Lift his head and turn it when lying on his stomach. By two months, the baby will be able to lift his head to 45 degrees and to 90 degrees by three months of age.

- Vocalize "ah", "oh", "ooh".

- Move legs in a bicycle-pedaling motion when lying on his back.

- Bring hand to mouth; Suck fingers.

- Express likes and dislikes; Cry when uncomfortable.

- Roll back to side.

- Start playing with feet.

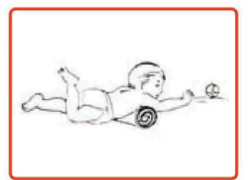

Place him/her face down (on tummy) to improve head control. Put toys around the baby so that he/she stays in this position and tries to reach the objects.

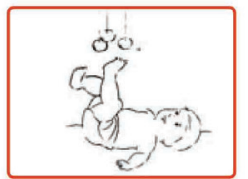

Encourage the baby to kick in the air or the toys hanging from the crib. Bicycle pedaling movements will enhance the child's muscle strength.

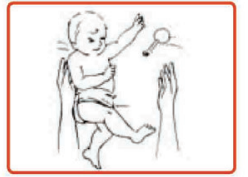

Encourage your baby roll over through play. Place him/her face down, grab one of the baby's legs and make it cross over from one side of the body to the other - the body will follow the movement.

\section{The child can/will:}

- Turn towards your voice; recognize parents

- Tell the difference between happy and sad faces.

- Pay attention. The baby listens when you talk.

- Reach with an extended arm to contact an object with the hand.

- Have a good head control.

- Follows/tracks object past midline.

- Observe his/her own hand and pick up objects with each hand (babies show no hand preference at this time).

- Have a greater sense of object permanence and causal relationships (for example, he/she looks for the rattle when hearing the sound, rather than just being scared).

- Play with feet more frequently.

- Roll from back to tummy purposefully - can also roll from tummy to back.

- Hold head steady at 90 degrees when playing on tummy.

- Sit with support or stand up using both hands.

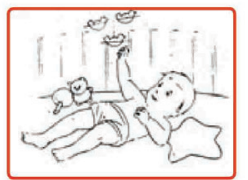

You can place objects in the crib in order to arouse the baby's interest and encourage him/ her to reach forward with outstretched arms.

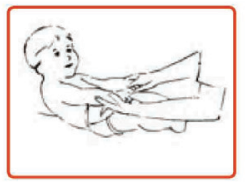

Play with the baby by sitting him/her in your leg. Then hold the child by the hand and pull him/her back and forth, following the rhythm of a song. Finally, in the last verse, the child is kept lying on your lap. This old child's play helps enhancing body contact with the baby and also strengthens his/her abdomen and neck muscles.

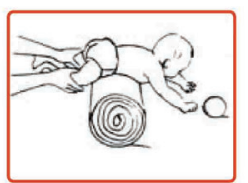

You can fold a mat or a blanket and make a roll, where the baby can experience a new game: reaching for toys on the floor while you hold him/her by the legs. Strengthening the back muscles is very important for better posture and so that the child can progress to more challenging positions such as the vertical ones (standing up). 


\section{The child can/will:}

- Sit unsupported.

- Go from supported sitting (at seven months) to sitting up unaided (at nine months).

- Indicate what he/she wants.

- Respond to a "no".

- Say mama, papa, dada.

- Crawl.

- Explore the environment.

- Lean on something to a standing position.

- Stand while holding on to furniture or to someone.

- Understand object permanence; play “hide-andseek".

- Bang things together.

- Finger feed.

- Grab two objects, one in each hand simultaneously. Transfer objects from hand to hand.

- Wave "good-bye".

- Have protective responses in the forward and sideto-side directions.

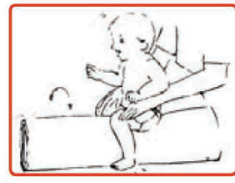

Take a cardboard box slightly larger than the body of the baby and make a tunnel so he/she can easily crawl through it. Place your baby on one side of the box and stay at the other as you call him/her.

With the child sitting on a stool at a table spread toys around so he/she can lower self and pick up the toys. Do not forget to switch sides!

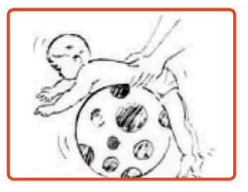

To stimulate speech development, toy phones are the best. Take a real phone and ask the child to talk to you using his/her play phone.

Balls! What child doesn't love a ball? If you place the child on stomach, lying on a ball, the vestibular system will be stimulated, which enhances balance.

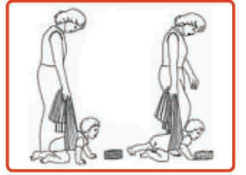

By using a towel or a sheet, you can encourage your baby's crawling developmen and give your child more stability in the hand-and-knees crawling position. Put toys around him/her so that it can be nice staying in this position for longer.

\section{The child can/will:}

- Stand alone, leaning on something to keep in this position.

- Walk holding on to someone's hand.

- Understand object permanence; discover a hidden toy under the body.

- Have good control over trunk and limbs when walking with support.

- Roll a ball to someone.

- Understand questions in context such as: "Where is your bottle?"

- Produce two or three words.

- Imitate actions; Use push-along toys.

- Point to things he/she wants.

- Assist when being dressed and undressed.

- Place cube in cup.

- Turn the pages of a book.

- Look for you.

- Shake head for "no".

- Drink from a glass.

- Throw objects.

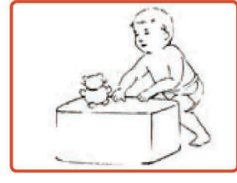

Gather multiple objects with interesting textures and of different types so that the child can touch and feel them as something hard (a wooden block) and something soft (a stuffed animal). Place your hand on the hard object you chose and say the name of the object followed by the word "hard", "hard block". Then place your hand on another hard object and do the same thing you did before: "hard table".

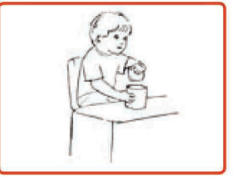

When the baby is nine or ten months old, sit on the floor and play with a set of stacking toys. Encourage your baby to do the same and in the end knock everything down.

Give paper so the baby can crush and tear it. It is training for motor coordination.

To stimulate speech development, toy phones are the best. Take a real phone and ask the child to talk to you using his/her play phone.

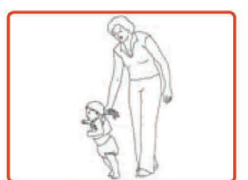

To encourage your baby to walk, a towel or a blanket can help maintain trunk stability, which makes them walk more firmly. 


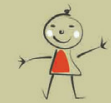

\section{The child can/will:}

\section{- Walk unsupported.}

- Kneel.

- Creep up stairs.

- Walk backwards. Walk fast. Walk sideways.

- Imitate scribbling.

- Assist when being dressed and undressed.

- Make a stack of 6 blocks.

- Throw a ball into a basket.

- Walk up stairs without help.

- Fit geometric shapes into slots

\section{- Hop.}

- Identify six parts of the body.

- Identify rooms in a house.

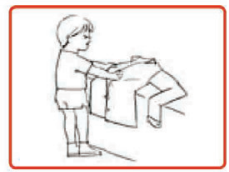

Let the child assist you dress and undress him/her. Also let him/her put his/her clothes in the hamper.

Help your baby identify body parts. Say "this is my nose" and put your finger on your nose. Then make your child put his/her finger on his/her nose as he/she says "this is your nose".

Encourage the child to make up and tell stories, adapting your voice to the "character" (if a monster has a rough voice, for instance). This will stimulate the child's creativity and attention.

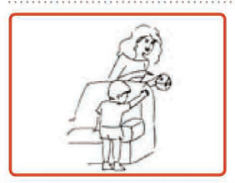

To encourage the child to walk more independently, place toys in higher sofas or tables and call the child's attention to that so he/she can move and pick up the toy.

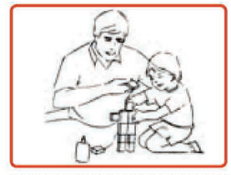

At this age puzzles must consist of a few pieces (four pieces), but that will be enough to stimulate the child's reasoning.

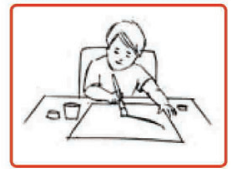

Cutting, pasting, drawing... These activities will promote the child's hand strengthening and coordination, besides being very entertaining.

\section{The child can/will:}

- Drink from a glass without assistance at fifteen months.

- Brush his/her teeth (4-5 years).

- Make use of four prepositions (3-5 years).

- Know about the usefulness of three objects (3 years).

- Identify colors (3 years).

- Set small pieces (3-4 years).

- Know how to use children's scissors (3-3.5 years).

- Have learned more than a thousand words ( 3 years).

- Know how to use a pencil correctly (4.5 years).

- Draw a person with 3-6 parts (3-5.5 years).

- Keep balance on one foot for around 6-8 seconds (4-5 years).

- Walk up stairs while placing one foot on each step (alternating gait) (3 years) and walk down stairs joining legs on each step.

- Draw a circle at 3.5 years, a cross at 4 and a square at 4.5 years.
Make your own bowling pins by using plastic soda bottles. Arrange the bottles and throw a ball towards them in order to knock them down.

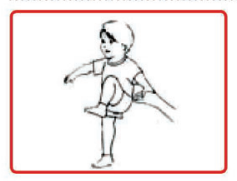

Dance a very lively music with the child so he/she can feel the rhythm and train to improve balance and motor coordination.

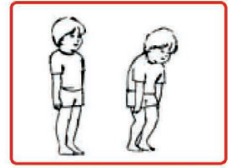

Choose a person to be the "master" and the others will be his/her "followers"; everything the 'master' does the 'followers' should repeat. Those who do not "follow the master" are out of play. Let the child be the master too.

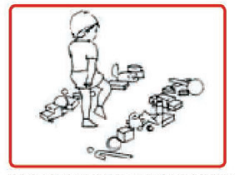

Make a trail of colorful paper or stacked toys on the floor, then forming a walkway for the child to walk within the limits defined by the paper or toys. You can even do other things, like jumping or walking on tiptoe.

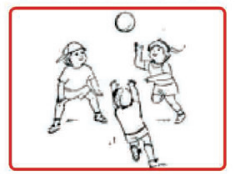

Playing ball, "hopscotch", jumping rope: simple games that can stimulate children to have a better command of the muscles and more balance and agility.

Set a place where the goal will be and let the child kick the ball. This wil make the child train to improve balance and accuracy. 


\title{
References
}

\begin{abstract}
- Formiga C K M R, Pedrazzani E S, Tudella E. Intervenção precoce com bebês de risco. Ed. Atheneu. São Paulo. 2010.

- Liddle T L, Yorke L. Coordenação Motora. Ed. M.Books do Brasil. São Paulo. 2007.

- Tisi, L. Estimulação precoce para bebês. Ed. Spring. Rio de Janeiro. 2004.

- Child Development 0 - 5 Years. Government Of Western Australia, Department of Health. Acesso em: 20/10/2014. Disponivel em: http://www.health.wa.gov.au/ordering .

- Desenvolvimento e Estimulação Precoce. Acesso em 15/10/2014. Disponível em: http://www.asin.org.br/ sindrome-de-down/14-desenvolvimento-e-estimulacaoprecoce.
\end{abstract}
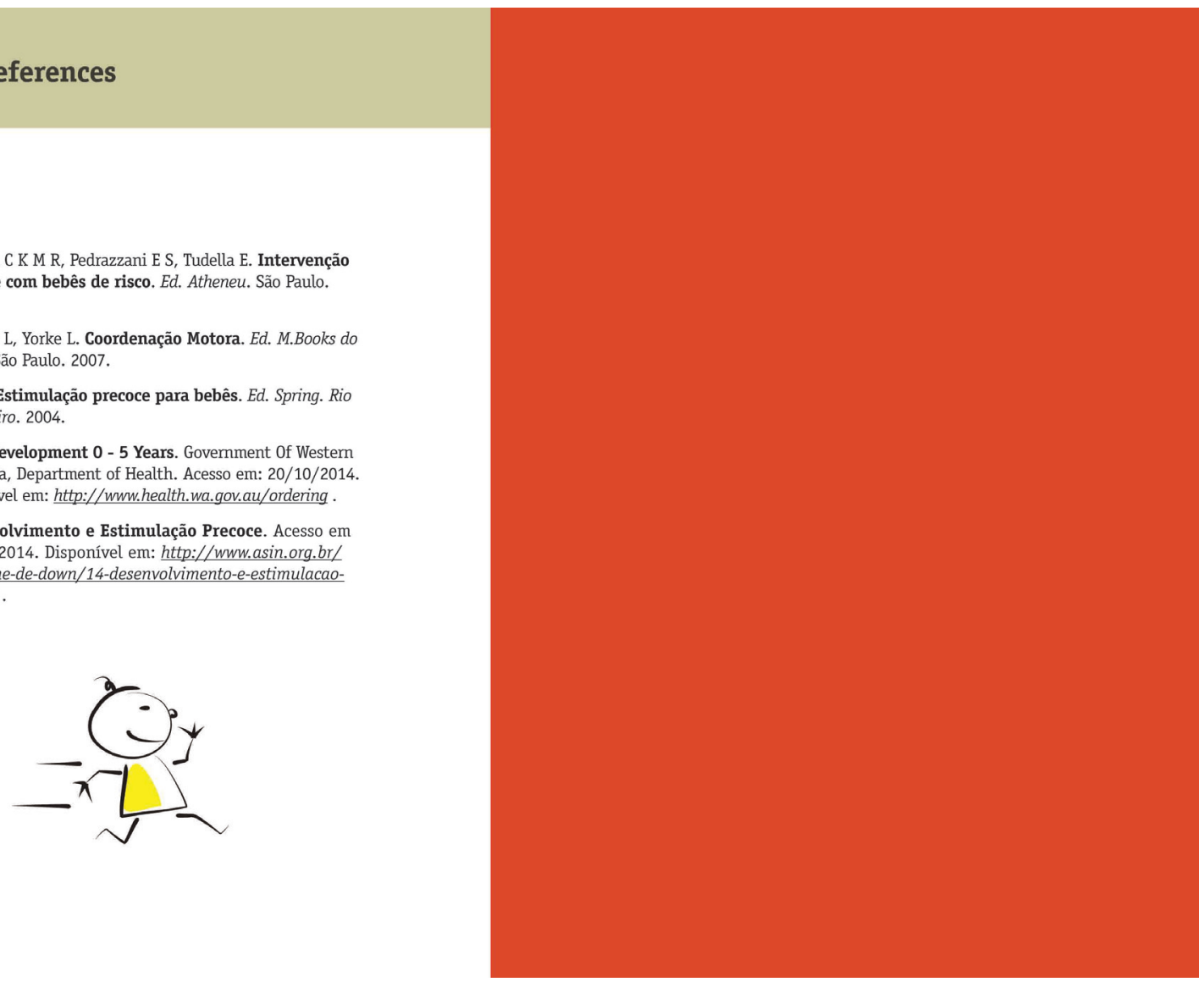

\section{RESUMO:}

Objetivo: avaliar a clareza e objetividade de uma cartilha com explicações detalhadas e ilustrações acerca do desenvolvimento neuropsicomotor de crianças de 0 a 6 anos por meio da análise de professores de creches, fisioterapeutas e cuidadores. Método: participaram 23 sujeitos, sendo 7 cuidadores, 7 professores e 9 fisioterapeutas. A Cartilha intitulada "Guia de orientações ao desenvolvimento de crianças de 0 a 6 anos" foi elaborada pelos pesquisadores e, posteriormente, avaliada pelos participantes por meio de um questionário. Resultados: a grande maioria dos participantes da pesquisa avaliou a cartilha como boa ou ótima (96\%). Todos consideraram a linguagem utilizada na cartilha como boa ou ótima e afirmaram que a aplicação deste material favoreceria a estimulação do desenvolvimento das crianças. Conclusão: a cartilha mostrou-se como uma medida prática e de baixo custo que pode auxiliar na estimulação do desenvolvimento infantil.

Palavras-chave: avaliação, material didático, creches, desenvolvimento infantil, orientação. 